\title{
Exploring the critical care nurses' experiences regarding moonlighting
}

\author{
BR Bhengu, M. Cur, School of Nursing, University of Natal, Durban
}

\begin{abstract}
While moonlighting is so prevalent amongst critical care nurses, there are no documented facts in this country about how it affects the nurses and the hospital management, considering the nature of their work that is both physically, mentally and emotionally strenuous. The aim of this study was to explore the critical care nurses' rationale and experiences regarding holding a second job (moonlighting). A non-experimental exploratory study was done using focus groups. Many positive and less positive experiences were revealed, for example, economical, educational, and psychosocial ones. Participatory control of moonlighting activity was suggested involving both management and staff at functional level.
\end{abstract}

\section{Samevatting}

Terwyl 'n tweede werk onder kritiese sorg verpleegkundiges aan die orde van die dag is, is daar geen gedokumenteerde feite in hierdie land oor hoe dit verpleegkundiges en die hospitaalbestuur beinvloed nie met in agneming van die feit dat die aard van die werk fisies, geestelik en emosioneel veeleisend is. Die doel van hierdie studie is om die kritiesesorgverpleegkundige se rasionaal en ervarings met betrekking tot 'n tweede werk te ondersoek. "n Nie- eksperimentele ondersoekende studie deur middel van fokusgroepe is gedoen. Baie positiewe en minder positiewe ervarings, byvoorbeeld, ekonomiese opvoedkundige en psigososiale faktore is geidentifiseer. Deelnemende beheer van die tweede werk deur beide verpleegbestuur en personeel op die funksionele vlak word voorgestel.

\section{Introduction}

Holding a second job or moonlighting has become prevalent amongst nurses especially critical care nurses. Half of the four hundred and sixty nine (469) nurses on the register of one of the four nursing agencies recruiting and supplying nurses for moonlighting in Durban are identified as critical care nurses, because of the demand for the nurses of this specialty in the private hospitals. It is also reported that some nurses apply directly to these hospitals as session workers while others leave their primary jobs and freelance through the agencies. The pool of nurses that are in the register in these agencies are predominantly from the public hospitals. (personal interview, member, Nursing Services of S.A, 1999).

\section{The Problem Statement}

While moonlighting is so prevalent amongst nurses, there are no documented facts in this country about how it affects the nurses and the hospital management, considering the nature of their work that is both physically, mentally and emotionally strenuous. Instead there is increased demand for nursing staff in private hospitals which are now more accessible with the increase in the medical aid provision to the previously underprivileged. The private institutions find it more economical to work with skeleton staff and call additional staff when the need arises. The pool of nurses that moonlight comes from the public sector. The government, as the employer in the public sector, is not being ready to compete with the private institutions in terms of incentives to retain nurses in the public sector (Sunday Tribune, 1999:2). Instead, like in other developing countries, further cuts in government spending on salaries are inevitable either through retrenchments or freezing of posts (Van der Gaag, Selcner \&
Vijverberg, 1989:V). It is postulated that there is a relationship between holding a second job and absenteeism in the public sector. It is also reported that some spend extraordinarily long hours in the second job to the detriment of their health (Van der Gaag, Selcner \&Vijverberg, 1989:30; Cohen, 1990:529 \& Urbach, 1994:797).

\section{The Purpose and Objectives of the study}

The purpose of this study was to explore the critical care nurses' rationale and experiences regarding holding a second job (moonlighting). The objectives were to:

- $\quad$ establish the critical care nurses' rationale for accepting and holding a second job;

- $\quad$ explore the critical care nurses' experiences of the second job and

- $\quad$ establish from the critical care nurses the need to support engagement in the second job and the way this should be done.

\section{The Significance of the study}

The prevalence of holding a second job especially, among critical care nurses, whose nature of work is so strenuous, has raised concern. The reported relationship between moonlighting and absenteeism including the effect of this activity on the physical health are also cause for concern both from the employee's and the management's perspective (Van der Gaag, et al, 1989:30; Cohen, 1990:529 \& Urbach, 1994:797).

Therefore exploring the critical care nurses' rationale for and 
their experiences of a second job could enable cooperation and understanding of all parties involved in balancing service, quality of care and education while limiting risk exposure. The benefit of guided moonlighting to the post graduate students could also be explored and taken advantage of.

\section{Definition of Terms}

Moonlighting is, according to Van der Gaag et al (1989:30), a second income earning activity in addition to the primary job, also called "double jobbing". Barnhart and Barnhart (1989) define it as the practice of holding or working at a second job, usually at night, in addition to a regular daytime job. It seems that the definition depends on the context in which it is used because Urbach (1994:794) defines it as an extracurricular employment in relation to academic programmes. In this study both versions were used.

Session work describes that type of moonlighting by nurses who are not recruited by nursing agencies but are listed directly in the hospital for call on a regular basis, according to need. These nurses may be part of the hospital staff doing something like overtime or may also be listed with the agencies (Personal interview, SA Nursing Services: 1999).

Freelance describes a type of work in which one performs or offers a service without being regularly employed (Mackwardt, Cassidy, Hayakawa \& McMillan: 1973).

Critical Care Nurses are all registered nurses working in Critical Care Units who have had experience with moonlighting either directly or indirectly.

\section{Literature review}

Existing literature on moonlighting focuses on resident doctors outside this country. The only nursing literature available expresses concern about the hospital malpractice insurance or physician insurance cover for moonlighting nurses (Muir, 1988). However, exposure to liability is a problem at any workplace, therefore in South Africa the insurance cover embraces all settings in which the insured is covered by a professional body or union. According to the member of the nursing agency that was visited, recruits for moonlighting are required to produce indemnity from a professional body or union. Secondly nurses are concerned about the legal duty to report this practice to management (Regan, 1981). Muir (1988), as an industrial relations consultant, advises the nursemanagers on facts to consider when they discover that a nurse is engaged in a second job, as follows:

- The impingement of the second job on the efficiency of the organisation or business interests of the principal job. In nursing this may imply sacrificing the quality of patient care when the nurse comes to the principal employment tired physically and mentally.

- $\quad$ The existence of competition between the primary and the second jobs may be unlikely with nurses although nurses can also set up a private nursing home which may bring about conflict of interests.

- Whether a clause in the contract of employment exists that forbids taking up a second job and whether this condition is absolute or conditional on the nurse seeking permission. This places the management in a better position to base their discipline on some tangible concrete facts.

- Common law which implies an unwritten contract of loyalty, fidelity, trust and confidentiality; is also sug- gested for consideration by the management when disciplinary action is taken.

- $\quad$ However, Muir (1988) also warns that a person has a right to work for whosoever he/she chooses and use the spare time to his/her advantage.

This being all that nurses have to say about moonlighting, the author decided to look for the subject under study among other health professionals. Literature on moonlighting among resident doctors indicates that moonlighting is a widespread practice so much that its prevalence is rated at $30 \%-60 \%$. This activity also varies among specialities with $6 \%$ among pathology, anaesthesiology, radiology, gynaecology and obstetrics; $30 \%$ in internal medicine and $70 \%$ in paediatrics. (Gullup \& Schnittling, 1991:387; Urbach, 1994:795). However, in nursing the register of the employment agency indicates that most moonlighting nurses are critical care nurses.

\section{Motives for moonlighting}

The main motive for moonlighting among other health workers was economic indebtedness related to salaries failing to keep pace with inflation, high interest rates and dependants (Cohen, 1990:1065; Gullup \& Schmittling, 1991: 387;Urbach, 1994:795). Studies also revealed that debts correlated with decision to moonlight and that higher resident salaries decrease the probability of moonlighting (Urbach 1994:795).

\section{Benefits of Moonlighting}

There are various benefits to moonlighting, for example, additional income that enables repayment of massive student loans thus improvement of the standard of living (Cohen \& Leeds, 1989:529).

Education is also enhanced through exposure to other treatment environments, promotion of self confidence to practise independently, promotion of ability to take responsibility, exploration of career opportunities with an experienced eye (Stange \& Sutherland, 1987; Urbach, 1994: 795).

Provision of an exciting change from one's daily work was seen to be an additional advantage to moonlighting (McCue, Janiszewski \& Stickley 1990:512).

\section{Concerns about moonlighting}

Many studies reveal a number of concerns about moonlighting in relation to competing needs, rights and principles as will be discussed hereunder.

Exhaustion is one important factor that causes concern as it affects efficiency in the performance of the job (Muir, 1988:34). Furthermore, a survey by Cheng (1991:1105) in California revealed that fatigue threatened medical judgement and compassion for patients, qualities that are so important for critical care nurses. Although a second job takes place after hours, Van der Gaag et al (1989:30) have made casual observation on absenteeism. suggesting that some of the moonlighting may be taking place during the day thereby enchroaching on the primary job.

Malpractice liability is of concern especially because some health workers have limited knowledge about liability insurance, to the extent that some may find out about it only after a lawsuit has been filed (Gullup \& Schmittling, 1991: $387-$ 388; Urbach et al 1994: 1512).

As alluded to earlier, conflict of interests and competition between the primary and secondary jobs may be a problem, for example, competition for specialised staff and well pay- 
ing clientele in the health care setting. Hence the observation that moonlighting varies with the area of specialisation (Urbach \& Richmond, 1994:1512).

Authors suggest that moonlighting be regulated in terms of duration, reporting, monitoring and/or approval. To achieve this authors recommend Peer Review Committees for collegial discipline and awareness workshops on professional liability insurance for moonlighters, including developing a policy to address moonlighting and handling situations with moonlighting employees. However, concern exists to the effect that regulation of moonlighting may suggest approval and supervisorv responsibility for this activity (Urbach, 1994:796; Gullup \& Schmittling, 1991:389; Yingling, Hattemer, Rouan \& Luke 1991:705; Lycos, 2000).

Whichever way is taken, regulatory measures to restrict or eliminate moonlighting practice, Cohen, \& Leeds (1989:531); Piening (1990:454) suggest that they must be balanced with the academic, clinical and financial realities.

\section{Research Methodology}

A non - experimental exploratory study was used to analyze the critical care nurses' rationale for and experiences of holding a second job. Twenty four (24) registered nurses working in the critical care units in two public hospitals in the Durban Functional Region were formed into four focus groups representing both shifts (day and night duty) according to their willingness to participate. The focus group discussions were conducted in the context of their primary jobs. For ethical reasons the participants were not selected according to whether they were moonlighting or not and they remained anonymous. A semi structured interview guide was used to trigger the shared with an experienced researcher and some of the research participants to verify the accuracy of the analyzed data.

\section{Findings}

The findings are presented according to the categories based on the interview guide.

\section{The extent of the activity}

All participants were moonlighting or had moonlighted in the recent past.

\section{The rationale for moonlighting}

All groups agreed that they moonlighted for economic reasons; " to augment the minimal government salaries"; "NPA salaries cannot carry you to month end".

One group pointed out that they were networking or exploring with an aim of changing to the private hospital; " if you have an interest of ending up working in private sector to orientate yourself".

The other group admitted that it was out of curiosity; as people talk about moonlighting more people want to experience it. "To experience what people talk about".

\section{Positive experiences: Economic}

\section{Cost awareness and cost containment}

All groups agree that moonlighting made them aware how expensive equipment and supplies are in hospital and embarked on cost containment even in their own hospitals, thus saving one's own hospital. This is illustrated in responses such as "charging in private hospitals makes you think how much we waste in the government hospitals not knowing how much things cost"'or "Now I see to it that unused gauze is sent back to CSD".

\section{Table 1: Interview Guide}

1. Tell me, have you moonlighted in the past three years?

2. Would you share with me the reason(s) that made you moonlight?

3. From your experience with moonlighting,

3.1. What were your positive experiences?

3.2. Were there less positive experiences?

4. What do you think the effect of moonlighting is:

4.1. In your work life?

4.2. In your private life?

5. Can moonlighting be made user friendly?

\section{Personal financial improvement}

The participants in all groups felt that they had gained financially because they could then make ends meet, and could afford to educate their children and avoid buying on account.

\section{Positive Experiences: Educational}

According to the participants, moonlighting fosters independence, self- confidence and responsibility through:

- exposure to a variety of diseases and

discussions. (See table 1).

\section{Data Analysis}

A content analysis of data was done manually whereby the data was formed into categories, namely, the extent of the moonlighting activity, positive and less positive experiences which were further categorized into economic, educational, psychosocial ones including physical health.

\section{Trustworthiness}

To ensure accuracy of fieldnotes and objectivity the focus group discussions were tape-recorded and transcribed verbatim with the permission of the participants. The analyzed data was

\section{technology to learn}

- $\quad$ update with new technology and drugs which the public hospitals cannot afford to buy.

Therefore moonlighting improves performance in their primary jobs. This is indicated by statements like; "I thought that after I had done an ICU course I was the best ..., I only realized after $I$ went to other hospitals that I did not have enough experience".

\section{Positive Experiences: Psychosocial}

The participants stated that the nurse-patient relationship and patient co-operation are facilitated by the fact that admission for patients in private hospitals are most of the time elective therefore patients are conscious and able to communicate. 
These patients are also well prepared for admission into ICU while those in public hospitals are usually admitted unconscious and often in an advanced stage of the disease to be able to communicate and co-operate. "in private patients are orientated and they are told that they will end up in ICU and this is what they will find therefore they are co-operative". Moonlighting has further allowed mixing of different racial and cultural groups which has established trust relationships and fostered mutual respect and understanding in these groups. "We get a chance to work with other races, they learn your culture and you learn theirs".

According to the participants moonlighting boosts people's morale and motivates them in their primary job because of:

- Exciting change from routine. The overtime that was offered at the government sector at some stage does not take you out of routine. "in your hospital - there is no change: same hospital, same work, same people, everything is the same".

- Appreciation by their authorities and incentives offered at secondary jobs. "in public one is never thanked and If things go wrong they are up in arms"; "you only see when you sign the report".

All groups of participants agree that moonlighting improves their quality of life because of the economic improvement in their households.

\section{Less positive experiences: Physical health}

Participants claimed that moonlighting can be very tiring and exhausting therefore may tempt people to go off sick especially those that overdo it. This they confirmed by saying that "there is no rest; people get tired and would go off sick".

\section{Less positive experiences: Economic}

The participants assert that moonlighting tempts people to live beyond their means therefore leads to a person wanting to moonlight more. This temptation encourages moonlighters to leave the country for more money thus contributes to brain drain from public to private hospitals and finally out of the country. "You feel moonlighting money in South Africa is not enough and get motivated to leave to work outside the country to make more money".

The participants were concerned that in private hospitals cost takes precedence over life. "I could not insert a naso-gastric tube to protect the patient from aspiration because of additional cost and, indeed, the patient did aspirate and was reintubated".

\section{Less positive experience: Psychosocial}

\section{Racism and Ethnocentrism}

According to the participants, language differences and lack of communication and trust among the different racial and ethnic groups threaten care. "Some speak Sotho, others Afrikaans and you can't understand"; "Sometime they write care plans in Afrikaans so that one cannot understand what happened during the day therefore they make the patient suffer". "White patients used to have negative attitudes and make you wonder if your nursing care will be sufficient or of acceptable standard".

\section{Habitual Moonlighting}

Participants claim that some of the moonlighters develop 'habitual moonlighting' by working almost continually without rest hence the temptation to go off sick when due to come back to the primary job. Statements that confirmed such a habit were; "Some work a few days in the shift and go off sick because the pay is not going to be affected; "It must ". "We will not deny that some people go off sick whenever they are supposed to come back from days off" It must also be noted though, that even those that do not moonlight do develop a tendency to go off sick".

\section{Differential Behaviour}

Participants stated that some of their colleagues work differently in the two jobs, for example, drag their feet in the primary job to save their energy for the secondary job. "Sometime people work differently, drag their feet, save their energy for moonlighting".

"You'll be surprised when you see people as they massage patients and smile, coming close to kissing them in the second job".

\section{Tension, fear and anxietv}

The participants maintain that they work under tension, fear and anxiety because of language differences, impatient doctors, ethnocentrism and lack of orientation in the secondary jobs. These further threaten patient care as alluded to, earlier. "When you come to a unit they just say 'here is the patient' and no one says anything (orientates you), you see to finish because you have come to make money". "Some feel you are worrying them if you ask".

\section{Jealousv bv permanent staff}

The participants interpret the questioning by the permanent staff as jealousy, for example; "when do you get time to rest? How do you manage to work so much? You must be having a carnow!"

\section{Less positive experiences: Patronage for/ Dependence on Moonlighters}

The participants have observed that most private hospitals depend totally on moonlighters to an extent of leaving the ICU with strangers only. "They leave the ICU totally to strangers". Stereotyping has also been observed if a nurse has made a mistake at some stage. "Sometime they undermine some hospitals if one nurse made a mistake from that hospital".

\section{Less positive experiences: Personal and family disorganisation}

\section{Neglect of familv}

The participants have found that they cannot schedule their time because they are expecting calls anytime to go moonlighting. They also found that they have neglected their families: "we miss out on homework for kids".

\section{Exploitation by familv members}

The husbands of moonlighters have been observed to exploit their wives and the whole family taking the moonlighter in the family for a money-maker and literary budgeting for them. "Husbands start making profit out of you, budget for you". "Kids look at you as money maker".

\section{Familv disorganisation}

Families of moonlighters have been observed to behave irresponsibly in the absence of their wives/mother. "He has an- 
other life when you are gone; children start doing their own things; no discipline". This is usually the beginning of a rift between husbands and wives.

\section{Making moonlighting user friendly}

\section{Inevitabilitv of Moonlighting}

The participants suggested that the management in the public sector must acknowledge that moonlighting is inevitable because of the need to earn extra cash and the demand for moonlighters in the private sector. "The management must accept that somehow everybody will need extra cash as long as there are no incentives with the public sector". "Nobody in her good senses would leave the comfort of her bed and go to work without a reason. We do like to be with our families". "Private hospitals do not employ a full complement of staff. they rely on moonlighters".

\section{Need to control}

The need to control moonlighting met with mixed feelings because two of the groups agreed that there is a need to have a policy such as restriction regarding the number of days or hours allowed to moonlight per certain period. However forbidding it would cause problems as quoted in one institution where it was forbidden and the staff resigned.

\section{Confrontation of habitual moonlighters}

The participants have observed that the people in charge of units tend to generalise about the problem of habitual moonlighters instead of just confronting them because the pattern is usually recognisable, yet if they report the sister may not be tactful. "Sisters in charge must not turn a blind eye"; "As long as you don't call my name I don't care". "If you report, the sister in charge will say, 'so and so came and complained" "

\section{Self Discipline}

The participants agreed that moonlighters must set their own limits and give themselves rest together with setting realistic goals in terms of budget. This is summarised in statements such as: "Set your own limits, give yourself rest; do not set high unrealistic goals; moonlighting is good for you if you have a conscience".

\section{Peer Group Discipline}

They also suggested that they could discipline each other though this seemed to be a source of other problems especially if peers are junior to the culprit or the latter is an aggressive person. "Talk to each other; some are aggressive; would not accept correction. But it is possible".

\section{Co-operation between the private and the public sector}

One group suggested the need for co-operation between the public and private hospitals to check if a person was officially off. How this could be done, needs to be worked out. They had no suggestions.

\section{Discussion and recommendations}

From the above findings it appears that moonlighting is much more prevalent than was anticipated as all participants were moonlighting. It also appears that moonlighting does not only affect the nurse employees but also management, whether positively or negatively. This compares with studies among medical residents who were pushed to moonlight by economic indebtedness as the salaries were failing to keep up with the inflation rate while their education was enhanced through varied and rich exposure (Stange and Sutherland 1987:64; Gullup \& Smittling 1991:387; Cohen 1990:1065 and Urbach 1994:795). The physical and mental health of the critical care nurses is of much concern especially when fatigue from moonlighting is associated with poor mental judgement and loss of compassion (Cheng, 1991:1105). It seems that the moonlighters are pointing fingers at the hospital management for the flaws in how they moonlight. The overtime that was once introduced by the Department of Health seemed to have some benefit but the problems with it was that there was no change from routine as also observed by McCue, Jaiszewski \& Stickley (1990:1512). There were also restrictions like in one hospital, for example, when on leave one would not be allowed to moonlight in one's own hospital. With this overtime they would only get paid after three months yet they needed immediate cash. The participants also claimed that they were tempted to misbehave when moonlighting in their own hospital, for example, they would remind colleagues that they were moonlighting therefore needed not to be overworked. It may be important to take the participants' recommendations seriously to regulate moonlighting, for example, this issue may need to be discussed openly in climate meetings. Moonlighting policy may need to be developed jointly between management and the nurses. Lycos (2000) recommend a moonlighting policy that does not necessarily regulate employees'off-duty conduct nor forbid them from having other jobs but focuses on issues like interference with the primary job, conflict of interest and approval of the additional employment. Peer Review Committees may have to be formed also as suggested by the moonlighters themselves and Yingling, Hattemer Rouan \& Luke (1991:705) to monitor and discipline moonlighters. It seems that the private hospitals where nurses moonlight need to develop clinical guidelines to ensure safety of patients in the hands of strangers (moonlighters), who are also exposed to malpractice liability. Affiliation to a union or professional society seems inevitable if one has to moonlight safetly.

\section{Further study}

The researcher suggests another study to explore the perceptions of the hospital management on moonlighting and their experiences with moonlighting activity among nurses in their hospitals.

\section{Limitations to the study}

Because of the small size of the sample in qualitative research one cannot generalise beyond the context of this study. Most of the available literature on the subject is old and not nursing as mentioned earlier probably due to the activity having assumed large proportions only recently.

\section{Conclusion}

This research has indicated that moonlighting is prevalent. It has also shown that moonlighting has some benefits. However, the disadvantages have pointed out that there is need to co-operate between the critical care nurses and the management regarding control of moonlighting. Whatever way is 
taken to regulate moonlighting, it is important to balance the academic, clinical and financial realities (Piening 1990:454).

\section{Acknowledgements}

Sincere appreciation for the guidance and assistance with this study from the following: Ass Professor A S Van der Merwe and Dr O Adejumo.

\section{List of Sources}

BARNHART, CL \& BARNHART, RK 1989: The World Book Dictionary, Volume One. London: World Book, Inc.

CHENG, TL 1991: House Staff Work Hours and Moonlighting: What Do Residents Want? A Survey Paediatric Residents in California. AJDC. 45, p104- 1108.

COHEN, RL 1990: Moonlighting. Letter to the editor. JAMA 263(8), p1065.

COHEN, SN \& LEEDS, MP 1989: The Moonlighting Dilemma, Balancing Education, Service and Quality Care While Limiting Risk Exposure, JAMA. 262(4), p529-531.

GULLUP, EM \& SCHMITTLING, G 1991: Liability Insurance for Moonlighting by Family Practice Residents, The Journal of Family Practice. 33(4), p387- 389.

LYCOS 2000 : wvsiwvg://13/http://www.lvcos.com/business/ cch/guidebook.html

McCUE, JD; JANISZEWSKI, M \& STICKLEY, W T 1990: Residents' Views of the Value of Moonlighting, Archives of Internal Medicine. 150, p1511- 1513.

MACKWARDT, AH; CASSIDY, FG; HAYAKAWA, SI \& MCMILLAN, JB 1973: Funk and Wagnalls Standard Dictionary of the English Language. International Edition, Volume Two, new York: Funk and Wagnalls.

MUIR, J 1988: Moonlighting, Nursing Times. 84(24), p34. Nursing Services of S.A. 1998. Personal Interview, 320 Building, Durban.

PIENING, RB 1990: Moonlighting: Making a Buck, Compassion, and Quality Control, JAMA. 264(4), p454.

STANGE, KC \& SUTHERLAND, JE 1987: Moonlighting Policy and Practice in Family Practice Residencies, The Journal of Family Practice. 24(1). p63-65.

Sundav Tribune. 1999. UK plundering our teachers and nurses, p2.

VAN DER GAAG,J; SELCNER, M \& VIJVERBERG, W 1989: Public- Private Sector Wage Comparisons and Moonlighting in Developing countries. Evidence from Cote d'Ivoire and Peru. LSMS Working Paper, Number 52, Washington D. C., The World Bank,

URBACH, JR 1994: Resident Moonlighting: Towards an Equitable Balance, Southern Medical Journal. August 1994, 87(8), p794- 800 .

YINGLING, KW; HATTEMER, C; ROUAN, GW \& LUKE, RG 1991: Internal Medicine Residents' Monitoring of their Colleagues' Moonlighting Activities at the University of Cincinnati, Academic Medicine. 66(11), p705- 706. 